\title{
Borrowings and Utilization of Agriculture Credit vis-a-vis Urbanization: A Case of Rural-Urban Interface in North of Bengaluru
}

\author{
Udaykumar, M.S. ${ }^{1 *}$ and Umesh, K.B. ${ }^{2}$
}

${ }^{1}$ Research Scholar, Department of Agricultural Economics, University of Agricultural Sciences, GKVK, Bengaluru, Karnataka, India ${ }^{2}$ Professor and University Head, Department of Agricultural Economics, University of Agricultural Sciences, GKVK, Bengaluru, Karnataka, India

*Corresponding author: msudaykumar94@gmail.com (ORCID ID: 0000-0001-8734-4946)

Received: 05-12-2020

Revised: 25-02-2021

Accepted: 02-03-2021

\begin{abstract}
The study was undertaken in North of Bengaluru to assess the quantum of credit borrowed, sources of credit and its utilization pattern by farm households across rural urban interface. The required primary data was collected from randomly selected 50 farmers each under rural, peri-urban and urban transacts. The results revealed that the farmers availed more credit from formal sources compared to informal sources across all transacts. Commercial banks occupied the prominent position in all the three transacts with a share of 52.25, 53.15 and 42.17 per cent in rural, peri-urban and urban areas, respectively followed by cooperatives among the formal sources. In case of informal sources, the amount borrowed was high in rural area $(40.06 \%)$ followed by peri-urban $(24.13 \%)$ and urban area $(15.89 \%)$. Furthermore, the amount borrowed among informal sources was more from the money lenders and commission agents. When crop loans are concerned, the peri urban farmers are more productive in proper utilization of the loans followed by urban and rural farmers. Credit borrowed in rural areas was primarily utilized on livestock (32\%), education (32\%) and bore well digging (22\%). Whereas, majority of farmers in peri-urban area and urban areas utilized credit for high value horticulture crops and livestock rearing. In case of high value crops, for digging of bore well and livestock rearing, the utilization percentage was cent per cent or even more in all the areas. It was because these crops will help in getting assured returns which is sufficient enough to meet their household expenditure when compared with the normal crop enterprises.

Highlights

(0 The quantum of credit borrowed per household was more in urban area followed by peri-urban and rural area.

0 Credit borrowed in rural areas was mainly utilized on livestock, education and bore well digging. Whereas, majority of farmers in peri-urban area and urban areas utilized credit for high value horticulture crops.
\end{abstract}

Keywords: Agriculture credit, Utilization, Formal and informal credit, rural-urban interface

If one wants to illustrate a near-perfect situation of vicious cycle of poverty, turning a blind eye on the fate of Indian farming community is quite impossible and it is an open and bitter truth as well. To interrupt this awful cycle, the dominant role that credit could play could be easily inferred from the lines of famous Estonian Economist Ragnar Nurkse i.e., "the main reason of vicious cycle of poverty is lack of capital formation". The dream of Doubling the Farmers' Income by 2022, traversing through

How to cite this article: Udaykumar, M.S. and Umesh, K.B. (2021). Borrowings and Utilization of Agriculture Credit vis-a-vis Urbanization: A Case of Rural-Urban Interface in North of Bengaluru. Economic Affairs, 66(1): 137-142.

Source of Support: None; Conflict of Interest: None 
once in a century economic crisis seems would still be a dream when the deadline approaches without a systematic overhaul of the sector, especially, the 'sphere of credit'. It is found from the study of NABARD conducted in various regions of India on the impact of credit on fertilizer consumption and crop that one per cent increase in credit supply increased fertilizer consumption by 0.30 per cent and one per cent increase in fertilizer consumption increased crop yields in range of 0.14 per cent to 1.13 per cent clearly reveals the compounding chain of vibes that the credit could put on. Even though there are several gaps in the present institutional credit delivery system like inadequate provision of credit to small and marginal farmers, paucity of term lending coupled with limited deposit mobilization and heavy dependence on borrowed funds by major agricultural credit purveyors, agriculture credit isstill playing an important role in supporting agriculture production in India (Abhiman et al. 2009).

Agricultural credit structure in India is broadly classified into Institutional (formal) and Noninstitutional (non-formal) credit. Former category comprises of Co-operative Banks, Regional Rural Banks and Commercial Banks, among others with the credit share of 10.9 per cent, 11.9 per cent and 77.2 per cent, respectively (Anonymous, 2019) and later includes landlords, agricultural moneylenders, professional money lenders, traders, commission agents, relatives and friends. Union Budget has fixed a credit of INR 16.50 lakh crores for FY22 with the backup of National Strategy for Financial Education 2020-25, launched by RBI in addition to series of such measures over the years (Anonymous, 2020). Total credit is divided into short term, medium term and long term with different credit structures lending out to different purposes according to the need. It does not matter how much resources one possess, if one doesn't know how to use them, it will never be enough. In the light of this, utilization of credit plays a key role in obtaining adequate returns, cushioning the risks and capacity to repay when it falls due which leads to mutual benefit of resource crunched farmers and creditors in the process as a whole. Three important factors such as timely and adequate availability of credit, proper utilization and prompt repayment of credit can lead to decent economic growth, development of agriculture and in particular Socio-economic development of the farm households. Utilization level in India is periodically assessed through Gross Non-Performing Assets, which currently hovers around 10 per cent of the gross advances, could also play a vital role in country's sovereign credit ratings (Anonymous, 2019).

With increasing rural and urban income differentials, advent of Fourth Industrial Revolution, wider livelihood options, better living conditions in cities, among others, Ministry of Housing and Urban Affairs has predicted that urban population may go beyond 50 per cent of total population by 2050 . Bengaluru Innovation Report, 2019 has forecasted that Bengaluru is going to be the fastest growing city in the world for the next 15 year. With this view, the present study has been taken up in the Bengaluru rural-urban interface to assess the agricultural credit scenario by splitting the study area into rural, periurban and urban with the following objectives:

- To analyze the quantum and sources of agricultural credit in the study area.

- To analyze the utilization pattern of loan amounts by the farmers in the study area.

\section{Methodology}

The present study was carried out across the ruralurban interface of north of Bengaluru in Karnataka during 2017. North transect was further divided into three layers namely rural, interface (peri-urban) and urban areas. The distinction of the areas into rural, interface (peri-urban) and urban areas was made based on the survey stratification index developed by considering percentage of built-up area and its linear distance from the city centre (Ellen et al. 2017). Vidhan Soudha, the building representing state legislature was usedas the reference point to measure the distance. Up to about 20 to $25 \mathrm{~km}$ away from the city centre, building density was strongly correlated to distance (the closer to the city, the higher the percentage of built-up area). Beyond that, however, the two parameters were negatively correlated. The present study focuses on the quantum of agriculture credit burrowed, purpose of credit and its utilization pattern by farm households across rural urban interface of north of Bengaluru. The villages were selected randomly across all the three transacts. The purposive multistage random 
sampling method was adopted for the selection of borrower farmer households. The sample frame consists of 150 farmers representing 50 each from the rural, peri-urban and urban areas, respectively.

\section{Nature and source of data}

In order to address the objectives of the study, data was obtained from the selected farmers using a pre-tested well-structured schedule developed for the study through personal interview. The information elicited from the respondent farmers pertained to the amount and purpose of credit borrowed from different sources, utilization pattern of borrowed credit etc., Data pertaining to both short term and term loans wascollected from the sample respondents across rural-urban interface of north of Bengaluru. In case of long term loans, the farmers who borrowed loan from the year 2013 were considered. The field survey was conducted during January-February, 2017.

\section{RESULTS AND DISCUSSION}

\section{Total credit borrowed by farmers from different sources}

Total credit borrowed from different sources indicated that the quantum of credit borrowed was more in urban (₹ 5,16,000) followed by peri-urban (₹ 3,77,000) and rural (₹ 2,97,000) area (Table 1).

Table 1: Total credit borrowed from different sources across rural- urban interface

\begin{tabular}{llll}
\hline $\begin{array}{l}\text { Study } \\
\text { area }\end{array}$ & $\begin{array}{l}\text { Formal sources } \\
\text { (₹) }\end{array}$ & $\begin{array}{l}\text { Informal } \\
\text { sources (₹) }\end{array}$ & Total (₹) \\
\hline Rural & $1,78,000$ & $1,19,000$ & $2,97,000$ \\
& $(59.93)$ & $(40.06)$ & $(100)$ \\
Peri- & $2,86,000$ & 91,000 & $3,77,000$ \\
urban & $(75.86)$ & $(24.13)$ & $(100)$ \\
& $4,34,000$ & 82,000 & $5,16,000$ \\
Urban & $(84.10)$ & $(15.89)$ & $(100)$ \\
\hline
\end{tabular}

Note: Figures in parentheses indicate per cent to total.

It was evident from the results that the total amount borrowed from formal sources was ₹ 1,78,000 in rural, ₹ 2,86,000 in peri-urban and ₹ 4,34,000 in urban areas which constituted 59.53, 75.86 and 84.10 per cent to the total credit borrowed, respectively. Whereas, 40.06 per cent of amount borrowed in rural, 24.13 per cent of amount borrowed in perurban and 15.89 per cent of the amount borrowed in urban areas was met from the informal sources. It is interesting to notice that farmers in rural areas borrowed more from informal sources compared to farmers in urban and peri-urban area. As we move from rural to urban areas the quantum of credit availed from formal sources was increasing whereas the quantum of credit availed from informal sources decreased.

\section{Quantum of credit borrowed by farmers from different formal and informal sources}

Quantum of credit borrowed by farmers from different formal and informal sources across ruralurban interface is depicted in Table 2. Results revealed that majority of farmers availed credit from formal sources than informal sources. The results are contradictory to study by Sisay (2008) wherein the author ascertained that only 43 per cent of the sampled farm households were formal credit users, andthe remaining 57 per cent were informal credit users, The results revealed that the quantum of loan availed was more from the formal sources (₹ 1.78 lakh, ₹ 2.86 lakh and ₹ 4.34 lakh in rural, peri-urban and urban area, respectively) when compared to informal sources ( $₹ 1.19$ lakh, ₹ 0.91 lakh and ₹ 0.82 lakh in rural, peri-urban and urban area, respectively). The results are in accordance with the study conducted by Anwarul and Prerna in 2015. Among the formal sources of credit, commercial banks occupied the prominent position in all the three transacts with a share of 52.25, 53.15 and 42.17 per cent in rural, peri-urban and urban areas, respectively followed by co-operative banks, RRB and MFIs. The results of Singh and Seema, (2003) aptly supported the findings of the study. The quantum of credit borrowed from cooperatives was ₹ 0.44 lakh in rural, ₹ 0.27 lakh in peri-urban and ₹ 2.08 lakh in urban areas which constitutes $24.72,9.44$, and 47.93 per cent of the total amount borrowed, respectively.

Self-help groups have touched highest share in rural areas as against peri-urban and urban areas due to the fact that, more number of SHGs were functioning in rural area than in urban area. Farmers in rural areas borrowed more amount from informal sources compared to farmers in urban and transition area. This could be due to 
Table 2: Quantum of credit borrowed by farmers from different formal and informal source across rural-urban interface ( $₹$ in lakh)

\begin{tabular}{|c|c|c|c|c|c|c|c|c|c|c|c|}
\hline \multirow[b]{2}{*}{ Study area } & \multicolumn{6}{|c|}{ Formal sources } & \multicolumn{5}{|c|}{ Informal sources } \\
\hline & $\begin{array}{l}\text { Commercial } \\
\text { banks }\end{array}$ & $\begin{array}{l}\text { Co- } \\
\text { operative } \\
\text { banks }\end{array}$ & RRB & MFIs & SHGs & Total & $\begin{array}{l}\text { Commission } \\
\text { agents }\end{array}$ & $\begin{array}{l}\text { Money } \\
\text { lenders }\end{array}$ & Relatives & Friends & Total \\
\hline Rural & $\begin{array}{l}0.93 \\
(52.25)\end{array}$ & $\begin{array}{l}0.44 \\
(24.72)\end{array}$ & $\begin{array}{l}0.06 \\
(3.37)\end{array}$ & $\begin{array}{l}0.08 \\
(4.49)\end{array}$ & $\begin{array}{l}0.27 \\
(15.17)\end{array}$ & $\begin{array}{l}1.78 \\
(100)\end{array}$ & $\begin{array}{l}0.25 \\
(21.01)\end{array}$ & $\begin{array}{l}0.68 \\
(57.14)\end{array}$ & $\begin{array}{l}0.18 \\
(15.13)\end{array}$ & $\begin{array}{l}0.08 \\
(6.72)\end{array}$ & $\begin{array}{l}1.19 \\
(100)\end{array}$ \\
\hline Peri-urban & $\begin{array}{l}1.52 \\
(53.15)\end{array}$ & $\begin{array}{l}0.27 \\
(9.44)\end{array}$ & $\begin{array}{l}0.38 \\
(13.29)\end{array}$ & $\begin{array}{l}0.42 \\
(14.69)\end{array}$ & $\begin{array}{l}0.27 \\
(9.44)\end{array}$ & $\begin{array}{l}2.86 \\
(100)\end{array}$ & $\begin{array}{l}0.19 \\
(20.88)\end{array}$ & $\begin{array}{l}0.31 \\
(34.07)\end{array}$ & $\begin{array}{l}0.38 \\
(41.76)\end{array}$ & $\begin{array}{l}0.03 \\
(3.30)\end{array}$ & $\begin{array}{l}0.91 \\
(100)\end{array}$ \\
\hline Urban & $\begin{array}{l}1.83 \\
(42.17)\end{array}$ & $\begin{array}{l}2.08 \\
(47.93)\end{array}$ & $\begin{array}{l}0.19 \\
(4.38)\end{array}$ & $\begin{array}{l}0.16 \\
(3.69)\end{array}$ & $\begin{array}{l}0.08 \\
(1.84)\end{array}$ & $\begin{array}{l}4.34 \\
(100)\end{array}$ & $\begin{array}{l}0.4 \\
(48.78)\end{array}$ & $\begin{array}{l}0.1 \\
(12.20)\end{array}$ & $\begin{array}{l}0.2 \\
(24.39)\end{array}$ & $\begin{array}{l}0.12 \\
(14.63)\end{array}$ & $\begin{array}{l}0.82 \\
(100)\end{array}$ \\
\hline
\end{tabular}

Note: 1. RRB -Regional Rural Banks, MFIs- Micro finance institutions, SHGs- Selp Help Groups; 2. Loan amount include both short term and term loans; 3. Figures in parentheses indicate percentage.

the low literacy rate in rural areas coupled with easy and timely accessibility to informal sources of credit. Among informal sources, money lenders $(57.14 \%)$ constituted highest share in rural areas followed by commission agents (21.01\%), relatives $(15.13 \%)$ and friends (6.72 \%). Among informal sources, the amount borrowed was more from the money lenders and commission agents because they provided timely and sufficient amount of money required by the - farmers. In peri-urban areas, 41.76 per cent of the amount borrowed was from relatives followed by money lenders (34.07\%), commission agents $(20.88 \%)$ and friends $(3.30 \%)$. Whereas, in urban area credit borrowed from commission agents $(48.78 \%$ ) constituted highest share followed by relatives $(24.39 \%)$, friends $(14.63 \%)$ and money lenders $(12.20 \%)$.

\section{Utilization pattern of credit by farmers across rural-urban interface}

Initially it was presumed that, farmer's credit utilization was unproductive and unintended. But in the study area, the utilization pattern had depicted (Table 3) a different scenario in which most of the credit taken was utilized for the purposes intended. Results revealed that each of the 16 sample respondents utilized credit for livestock rearing and education (32\%) and nine farmers utilized credit for dwelling house (18\%) in rural area. Whereas in case of peri-urban area, 28 per cent of sample farmers used borrowed credit for livestock rearing followed by growing high value crops (26 $\%)$ and crop production (20\%). Seventeen urban farmers utilized credit for growing high value crops which constitutes 34 percent followed by crop loan $(26 \%)$ and livestock rearing (22\%). It is interesting to observe that most of the rural farmers used borrowed amount for livestock rearing, education and dwelling house whereas peri-urban and urban farmers utilized borrowed amount for growing high value crops, livestock and agriculture crops (Fig 1).

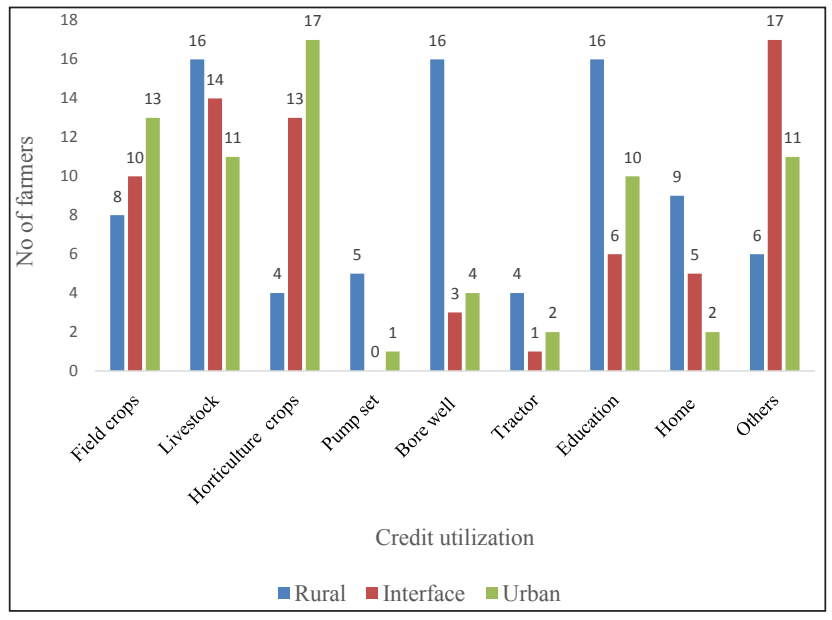

Fig. 1: Utilization pattern of credit by farmers across rural-urban interface

Farmers in peri-urban (26\%) and urban (34\%) areas utilized credit for high value horticulture crops. As a result of urbanization, high-value horticulture crops have assured market and has more potentiality in increasing farm income (Birthal et al. 2007). In case of peri urban area, about six farmers utilized credit for commercial lawn cultivation (12\%) and five farmers utilized credit for purchasing vehicles (10\%). The credit facilities extended by the institutional and non-institutional sources to the agriculture and non-agriculture purpose have 
been utilized by farmers based on their needs. Many times, the utilization of credit for the specific purpose was not cent per cent. Credit borrowed in rural area was mainly utilized on livestock (32\%) and bore well digging ( $22 \%$ ). This is due to the fact that livestock provides assured income throughout the year in dryland areas.

Table 3: Utilization pattern of credit by farmers across rural-urban interface (No. of farmers)

\begin{tabular}{llll}
\hline Particulars & $\begin{array}{l}\text { Rural } \\
(\mathbf{n}=50)\end{array}$ & $\begin{array}{l}\text { Peri-urban } \\
(\mathbf{n}=50)\end{array}$ & $\begin{array}{l}\text { Urban } \\
(\mathbf{n}=50)\end{array}$ \\
Live Stocks Purchase & $16(32)$ & $14(28)$ & $11(22)$ \\
\hline Education & $16(32)$ & $6(12)$ & $10(20)$ \\
Bore Well & $11(22)$ & $3(6)$ & $3(3)$ \\
Dwelling House & $9(18)$ & $5(10)$ & $2(4)$ \\
Crop loan & $8(16)$ & $10(20)$ & $13(26)$ \\
Pump Set & $5(10)$ & $0(0)$ & $1(2)$ \\
High Value Crops & $4(8)$ & $13(26)$ & $17(34)$ \\
Green house & $4(8)$ & $0(0)$ & $2(4)$ \\
Tractor & $4(8)$ & $1(2)$ & $2(4)$ \\
Marriage & $2(4)$ & $1(2)$ & $2(4)$ \\
Poultry & $1(2)$ & $0(0)$ & $6(12)$ \\
Land development & $1(2)$ & $0(0)$ & $3(6)$ \\
Medical expenditure & $1(2)$ & $1(2)$ & $2(4)$ \\
Family expenditure & $1(2)$ & $3(6)$ & $3(6)$ \\
Lawn(Commercial) ${ }^{*}$ & $0(0)$ & $6(12)$ & $0(0)$ \\
Vehicles & $0(0)$ & $5(10)$ & $3(6)$ \\
Real estate & $0(0)$ & $0(0)$ & $2(4)$ \\
\hline
\end{tabular}

Note: Figures in parentheses indicate percentage; *-commercial lawn cultivation for sale.

The utilization percent of credit in three different areas of north transact is presented in Table 4 . The crop loan obtained by the respondents in rural, peri-urban and urban areas were not utilized cent per cent for the purpose of crop production, instead their utilization was only 38 per cent, 71 per cent and 68 per cent, respectively. Most of the times the loan sanctioned was being utilized in different ways. This situation may arise due to insufficient funds with the farmers, less income generation from agricultural and non-agricultural sources. Farmers once they avail the loan, start fulfilling their urgent personal and household needs. This was the scenario amongst majority of the rural - farmers Sarkar and Hussain (2010) also reported that the borrower farmers in study area used about 55.23 percent of their credit for non-agricultural purposes. As, their economic condition was so poor, they used their credit for non-agricultural purposes viz., food consumption, purchase of cloth, educational expenses, medical expenses, repayment of old debt and so on. Both in rural and urban areas, entire amount of livestock loan was utilized for livestock rearing but in peri-urban area, the utilization was only 93 per cent.

Table 4: Utilization of credit for the purpose it was intended in percent

\begin{tabular}{|c|c|c|c|c|c|c|}
\hline \multirow[b]{2}{*}{ Particulars } & \multicolumn{2}{|c|}{ Rural (n=50) } & \multicolumn{2}{|c|}{$\begin{array}{l}\text { Peri-urban } \\
(n=50)\end{array}$} & \multicolumn{2}{|c|}{ Urban $(n=50)$} \\
\hline & 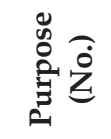 & 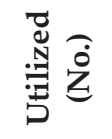 & 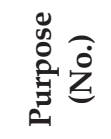 & 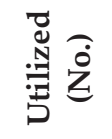 & 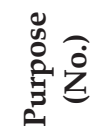 & 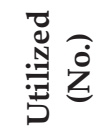 \\
\hline Crop loan & 21 & $8(38)$ & 14 & $10(71)$ & 19 & $13(68)$ \\
\hline Live Stock & 16 & $\begin{array}{c}16 \\
(100)\end{array}$ & 15 & $14(93)$ & 11 & $\begin{array}{c}11 \\
(100)\end{array}$ \\
\hline $\begin{array}{l}\text { High value } \\
\text { crop }\end{array}$ & 4 & $4(100)$ & 12 & $\begin{array}{c}13 \\
(108)\end{array}$ & 14 & $\begin{array}{c}17 \\
(121)\end{array}$ \\
\hline Bore Well & 9 & $\begin{array}{c}11 \\
(122)\end{array}$ & 3 & $3(100)$ & 3 & $3(100)$ \\
\hline Pump Set & 3 & $5(167)$ & 0 & $0(0)$ & 1 & $1(100)$ \\
\hline Education & 10 & $\begin{array}{c}16 \\
(160)\end{array}$ & 6 & $6(100)$ & 14 & $10(71)$ \\
\hline $\begin{array}{l}\text { Green } \\
\text { house }\end{array}$ & 4 & $4(100)$ & 0 & $0(0)$ & 2 & $2(100)$ \\
\hline $\begin{array}{l}\text { Dwelling } \\
\text { house }\end{array}$ & 8 & $9(113)$ & 1 & $5(500)$ & 2 & $2(100)$ \\
\hline Poultry & 1 & $1(100)$ & 0 & $0(0)$ & 4 & $6(150)$ \\
\hline Tractor & 3 & $4(133)$ & 1 & $1(100)$ & 2 & $2(100)$ \\
\hline Others & 4 & $5(125)$ & 16 & $\begin{array}{c}16 \\
(100)\end{array}$ & 10 & $\begin{array}{c}15 \\
(150)\end{array}$ \\
\hline
\end{tabular}

Note: Figures in parentheses represent per cent utilization.

In case of high value crops, the utilization percentage was 100 per cent in rural area but in peri-urban and urban areas, it was more than 100 per cent (i.e., $108 \%$ and $121 \%$, respectively). This is because the high value crops yield assured returns which is sufficient enough to meet their household expenditure when compared with the normal crop enterprises. The respondents in peri-urban and urban areas utilized 100 per cent of the bore well loan for the specific purpose but in case of rural area borrowers utilized more than 100 per cent, which means they have diverted the loan amount from others to digging of bore well. This might be due to the increasing demand for water in agriculture and allied enterprises, which coincided with lack 
of normal rainfall in recent - years The results are in line with the study of Rohin et al. (2017) where in the authors reported that tubewell/pumping set loan was fully utilized by farm households.

\section{CONCLUSION}

The quantum of credit borrowed per household was more in urban area followed by peri-urban and rural area. Among formal sources of credit, commercial banks occupied the prominent position in all the three areas with a share of 52.25, 53.15 and 42.17 per cent in rural, peri-urban and urban areas, respectively. In case of informal sources, the amount borrowed was high in rural area (40.06 \%) followed by peri-urban $(24.13 \%)$ and urban area $(15.89 \%)$. When crop loans are concerned, the peri urban farmers are more productive in proper utilization of the loans followed by urban and rural - farmers Credit borrowed in rural areas was mainly utilized on livestock (32\%), education (32\%) and bore well digging (22\%). Whereas, majority of farmers in peri-urban area and urban areas utilized credit for high value horticulture crops. In case of high value crops, the utilization percentage was 100 per cent in rural area but in peri-urban and urban areas, this was more than 100 per cent (i.e.108 \% and $121 \%$, respectively) because high value crops yield assured returns which is sufficient enough to meet their household expenditure when compared with the normal crop enterprises. Miss-utilization of the farm loans was due to insufficient funds with the farmers, less income generation from agricultural and non-agricultural sources. With all the efforts from government still few farmers are availing loan from the informal sources because of lengthy procedure, non-availability of consumption loan etc., Hence, loan procedure should be simplified by reducing documentation which will increase the accessibility of credit from formal sources. This helps in curtailing farmers approach towards informal sources. A provision for enhanced consumption loan must be included, in the existing loan components as it can lessen the mis-utilization of loans. Attention must also be given to redesign the collateral security norms especially for marginal and small farmers.

\section{ACKNOWLEDGEMENTS}

The authors wish to thank, farmers for sparing their valuable time in providing precious information. This work was carried out in collaboration between authors. Author conducted a study during his Masters work (2017) and he designed the study, performed the statistical analysis, wrote the protocol and wrote the complete manuscript. Author Dr. K.B. Umesh is the major advisor/guide for my master's degree, and he corrected the manuscript, guided me regarding how to conduct the study and select the tools for analysis, etc.

\section{REFERENCES}

Anonymous. 2019. Annual report 2019-20. National Bank for Agriculture and Rural Development.

Anonymous. 2020. Summary of the Union Budget 2021-22. Ministry of Finance, Government of India.

Das, A. and Senapati, M. and John, J. 2009. Impact of Agricultural Credit on Agriculture Production: An Empirical Analysis in India. Reserve Bank of India Occasional Papers, 30(2): 75- 106.

Ellen, M.H., Monish, J., Nils, N. and Thomas, M. 2017 Construction and use of a simple index of urbanization in the rural-urban interface of Bangalore, India. Sustainability, pp. 1-21.

Hoda, A. and Terway, P. 2015. Credit policy for agriculture in India - An evaluation. Working Paper 302, pp. 1-31.

John, R., Kumar, D. and Ratnam, S. 2017. Pattern of utilization of agricultural credits among KCC credit holding farmers of Allahabad District UP. Int. J. Acade. Res. Dev., 2(3): 21-23.

Sarkar and Hussain, 2010. Comparative analysis of borrower and non-borrower Boro rice farmers in some selected sites of Mymensingh district, Bangladesh. J. Agril. Res., 35(1): 65-76.

Singh, A.K. and Joshi, S. 2003. Institutional financing through cooperative and commercial banks in India. Kurukshetra, 25(22): 32-37.

Singh, B.P., Joshi, P.K., Roy, D. and Thorat, A. 2007. Diversification in Indian agriculture towards high-value crops. IFPRI Discussion Paper, pp. 1-29.

Yehuala, S. 2008, Determinants of smallholder farmers' access to formal credit: The case of Metema Woreda. M.Sc. Thesis (Unpub.), Haramaya University, North Gondar, Ethiopia. 